\title{
Hidden subsurface garden on own faeces - the trace fossil Tubulichnium rectum (Fischer-Ooster, 1858) from the Cretaceous-Palaeogene deep-sea sediments
}

\author{
Alfred Uchman and Andreas Wetzel
}

\begin{abstract}
Tubulichnium rectum (Fischer-Ooster, 1858) is an oblique to horizontal, unbranched, blind ending tube having margins densely lined with ellipsoidal muddy pellets. It occurs in fine sandy to muddy, siliciclastic and marly deep-sea sediments mostly from Turonian to Eocene times. It was probably produced by "worm"-like organisms, which fed on organic-rich sediment deposited seasonally or episodically on the sea floor. The faecal pellets were stored in the deep parts of the burrow within the anoxic zone beyond the depth that other burrowers usually penetrate. During periods of food shortage, the pellets were utilized as a supplementary nutrition source. Such behaviour in constructing and using a cache is interpreted as an adaptation to increased competition for food in the deep sea after the Cenomanian.
\end{abstract}

Alfred Uchman. Institute of Geological Sciences, Jagiellonian University, Gronostajowa 3a, PL 30-387 Kraków, Poland; alfred.uchman@uj.edu.pl

Andreas Wetzel. Geologisches Institut, Universität Basel, Bernoullistrasse 32, CH-4056 Basel, Switzerland; andreas.wetzel@unibas.ch

Keywords: ichnology; ichnotaxonomy; autocoprophagy; cache; flysch; turbidites

Submission: 26 April 2017 Acceptance: 4 August 2017

\section{INTRODUCTION}

Trace fossils record variable strategies of feeding by their producers, which include systematic utilization of deposits in horizontal, vertical, or oblique directions, random sediment reworking, filter feeding, predation, chemo(sym)biosis, farming, etc. (for a review see Seilacher, 2007; Vallon et al., 2016). Owing to seasonal oligotrophy or general oligotrophy, efficiency of these strategies is challenging in the deep-sea, where supply of organic matter is, on average, rather low and commonly strongly fluctuating (e.g., Lutz et al., 2007; Arndt et al., 2013). Under such conditions, competition between organisms forces them to develop nutritional strategies most of which are still poorly known. Theoretically one strategy is to ingest as

Uchman, Alfred and Wetzel, Andreas. 2017. Hidden subsurface garden on own faeces - the trace fossil Tubulichnium rectum (Fischer-Ooster, 1858) from the Cretaceous-Palaeogene deep-sea sediments. Palaeontologia Electronica 20.2.40A: 1-18 palaeo-electronica.org/content/2017/1968-tubulichnium-deep-sea-trace

Copyright: August 2017 Palaeontology Association. This is an open access article distributed under the terms of AttributionNonCommercial-ShareAlike 4.0 International (CC BY-NC-SA 4.0), which permits users to copy and redistribute the material in any medium or format, provided it is not used for commercial purposes and the original author and source are credited, with indications if any changes are made.

creativecommons.org/licenses/by-nc-sa/4.0/ 


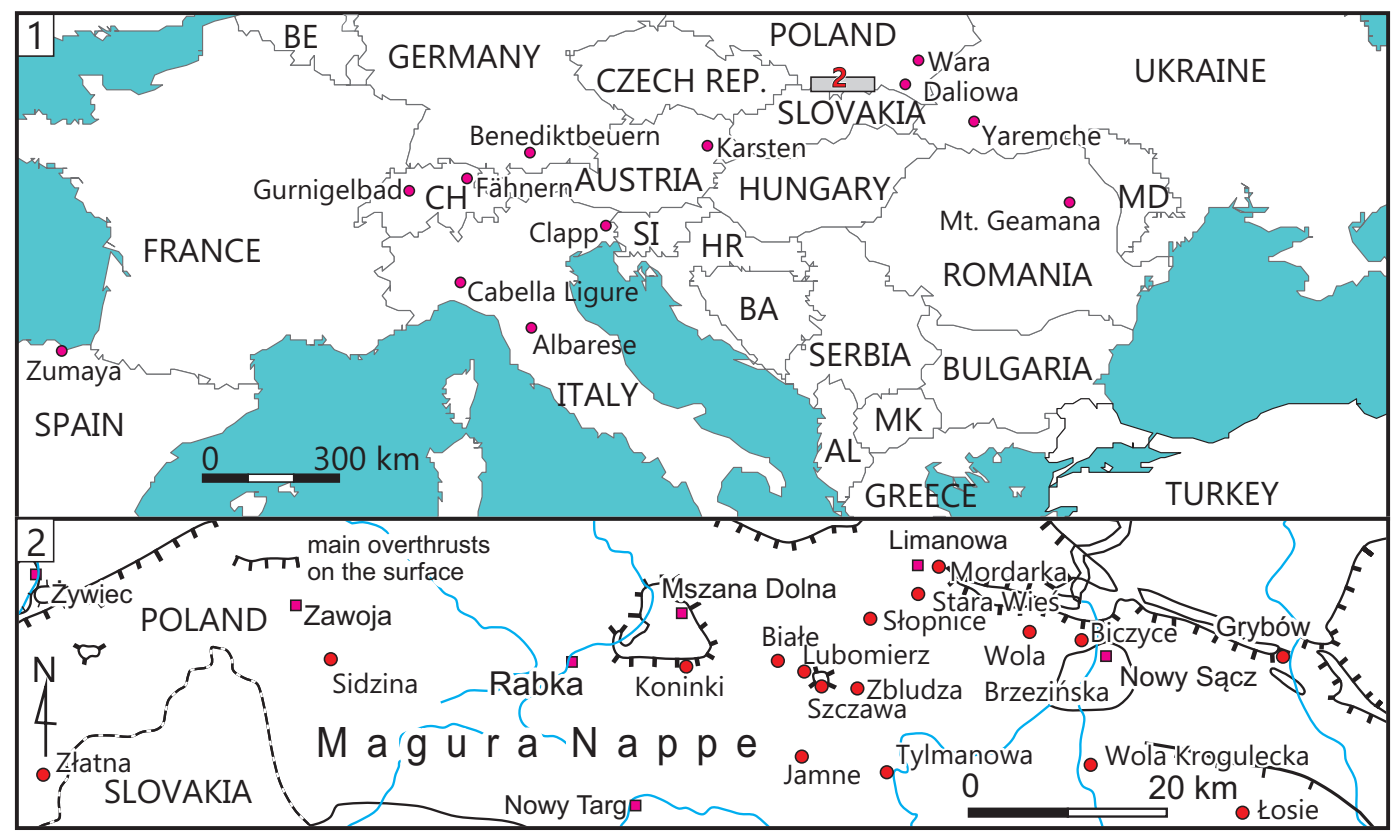

FIGURE 1. Location maps: 1, a part of Europe with main localities of the material studied and indication of the main study area in the Polish Carpathians; 2, the main study area in the Polish Carpathians with indication of several localities of the material studied or reported occurrences of Tubulichnium rectum.

much as possible during times of food abundance and utilize one's own, possibly fermented, faeces as a new food resource during times of nutritional misery.

A good example of this strategy is represented by the trace fossil that was described originally as Halymenites von Sternberg, 1833 and later as Tubulichnium Książkiewicz, 1977 or Ophiomorpha Lundgren, 1891. However, morphology, ethological function, and environmental meaning of this trace fossil are still poorly understood. It is the purpose of this paper to: (1) provide an ichnotaxonomic revision of this trace fossil on the basis of the original material, (2) investigate the morphology and occurrences on the basis of newly sampled additional material from the Polish Carpathians, and (3) propose a new ethological model of the discussed trace in connection with neoichnological data from the modern deep sea.

\section{MATERIAL AND METHODS}

\section{Material}

The specimens analysed derive from many localities (Figure 1.1). However, the specimens for morphological studies were collected mostly from the Ropianka Formation (Campanian-Paleocene) of the Magura Nappe in the Polish Flysch Carpathians in the Słopniczanka River section at Słopnice and Zamieście (Figure 1.2). This formation con- sists of turbiditic sandstones, siltstones, mudstones, and marls. The discussed trace fossil was observed mainly in thin- to medium-bedded turbiditic sediments, which occur in three thrust sheets; these sediments are interbedded with isolated packages of thick sandstone and rarely pebbly mudstone beds (Uchman, 2008b). Additional observations were made in the Rhenodanubian Flysch of the Alps in Austria and Germany (Uchman, 1999), and the Pagliaro Formation (Paleocene) in the Ligurian Domain of the Northern Apennines (Uchman 2007a). All of these deposits consist of deep-sea turbiditic sediments. A list of the occurrences of the discussed trace fossils known by the authors is given in Table 1, together with the relevant literature.

The original material of Halymenites FischerOoster, 1858 is preserved in marl. It was collected from the Gurnigel Nappe in the Fribourgian Alps (Switzerland). The Gurnigel Nappe is composed mainly of siliciclastic turbiditic deposits and only subordinately of marls with intercalated turbidites. The marly deposits are Maastrichtian in age, while siliciclastics accumulated during the Palaeogene (van Stuijvenberg, 1979). The marly beds are restricted within the type region mentioned by Fischer-Ooster (Seeligraben) to a rather small area (roughly at Swiss coordinates 601'060/176'450; Schweizerische Geologische Kommission, 1961). 
TABLE 1. Occurrences of Tubulichnium rectum (Fischer-Ooster, 1858). * - reserve inclusion in T. rectum; ${ }^{* *}$ - probably not $T$. rectum.

\begin{tabular}{|c|c|c|c|c|}
\hline $\begin{array}{c}\text { Formation and general } \\
\text { location }\end{array}$ & Localities & Age & Facies & References \\
\hline $\begin{array}{l}\text { Al Ayn Formation, } \\
\text { Oman }\end{array}$ & & Upper Triassic & $\begin{array}{l}\text { Deep-sea turbiditic } \\
\text { sandstones and } \\
\text { shales }\end{array}$ & Wetzel et al. (2007) \\
\hline $\begin{array}{l}\text { Globotruncana Marl, Pieniny } \\
\text { Klippen Belt, Carpathians, } \\
\text { Poland }\end{array}$ & Sromowce Wyżne & Turonian & $\begin{array}{l}\text { Deep-sea, pelagic } \\
\text { and hemipelagic } \\
\text { sediments }\end{array}$ & Książkiewicz (1977) \\
\hline $\begin{array}{l}\text { Zementmergelserie, } \\
\text { Rhenodanubian Flysch, } \\
\text { Bavarian Alps, Germany }\end{array}$ & $\begin{array}{l}\text { Kalkgraben quarry, } \\
\text { Arzbach Stream, Steinbach } \\
\text { near Benediktbeuern, } \\
\text { Halbammer Valley }\end{array}$ & $\begin{array}{l}\text { Turonian- } \\
\text { Maastrichtian }\end{array}$ & $\begin{array}{l}\text { Turbiditic } \\
\text { limestones, } \\
\text { marlstones and } \\
\text { mudstones }\end{array}$ & Uchman (1999) \\
\hline $\begin{array}{l}\text { Sromowce Beds, Pieniny } \\
\text { Klippen Belt, Carpathians, } \\
\text { Poland }\end{array}$ & Sromowce Wyżne & $\begin{array}{l}\text { Coniacian- } \\
\text { Maastrichtian }\end{array}$ & $\begin{array}{l}\text { Deep-sea turbiditic } \\
\text { sandstones and } \\
\text { shales }\end{array}$ & Książkiewicz (1977) \\
\hline $\begin{array}{l}\text { Holovnia Marl, Skole Nappe } \\
\text { Carpathians, Poland }\end{array}$ & Krzeczkowa - old quarry & $\begin{array}{l}\text { Coniacian- } \\
\text { Santonian }\end{array}$ & Deep-sea marls & This study \\
\hline $\begin{array}{l}\text { Ropianka Formation } \\
\text { (Inoceramian Beds), Skole } \\
\text { Nappe, Carpathians, Poland, } \\
\text { Ukraine }\end{array}$ & $\begin{array}{l}\text { Poland: Wara, Wołodź, } \\
\text { Kuźmina, Bachów, } \\
\text { Huwniki, Kalwaria } \\
\text { Pacławska (the steram } \\
\text { Sopotnik), Wola } \\
\text { Romanowa. Ukraine: Dora } \\
\text { (Yaremche) }\end{array}$ & $\begin{array}{l}\text { Coniacian- } \\
\text { Paleocene }\end{array}$ & $\begin{array}{l}\text { Deep-sea turbiditic } \\
\text { sandstones and } \\
\text { marls }\end{array}$ & $\begin{array}{l}\text { Książkiewicz (1977); } \\
\text { this study }\end{array}$ \\
\hline $\begin{array}{l}\text { Kropivnik Fucoid Marls, } \\
\text { Skole Nappe, Carpathians, } \\
\text { Poland }\end{array}$ & Wiar section & $\begin{array}{l}\text { Campanian- } \\
\text { lower } \\
\text { Maastrichtian }\end{array}$ & Deep-sea marls & Leszczyński (2004) \\
\hline Tuscan Apennines, Italy & Alberese & $\begin{array}{l}\text { Campanian- } \\
\text { Eocene }\end{array}$ & Deep-sea marls & $\begin{array}{l}\text { Reis (1909); Abel } \\
(1935) ; \\
\text { Seilacher (1959) }\end{array}$ \\
\hline $\begin{array}{l}\text { Monte Antola Formation, } \\
\text { Ligurian Domain, Northern } \\
\text { Apennines, Italy }\end{array}$ & $\begin{array}{l}\text { Vagge, Molino Vecchio, Val } \\
\text { Gardenella, Monte Colletto, } \\
\text { Candini, Roiale }\end{array}$ & $\begin{array}{l}\text { Late Campanian } \\
\text { - Maastrichtian }\end{array}$ & $\begin{array}{l}\text { Deep-sea turbiditic } \\
\text { marls, sandstones } \\
\text { and shales }\end{array}$ & Uchman (2007b, 2009) \\
\hline $\begin{array}{l}\text { Northpenninic Flysch, Alps, E } \\
\text { Switzerland }\end{array}$ & Fähnernspitz Mt. & $\begin{array}{l}\text { Upper } \\
\text { Cretaceous }\end{array}$ & $\begin{array}{l}\text { Deep-sea turbiditic } \\
\text { marls, sandstones } \\
\text { and shales }\end{array}$ & Fischer-Ooster (1858) \\
\hline $\begin{array}{l}\text { Ropianka Formation, Magura } \\
\text { Nappe, Carpathians, Poland }\end{array}$ & $\begin{array}{l}\text { Złatna, Mordarka, Biczyce, } \\
\text { Wola Brzezińska, Wola } \\
\text { Krogulecka, Siary, Uście } \\
\text { Gorlickie, Koninki, Stara } \\
\text { Wieś, Lubomierz, Słopnice }\end{array}$ & $\begin{array}{l}\text { Maastrichtian- } \\
\text { Paleocene }\end{array}$ & $\begin{array}{l}\text { Deep-sea turbiditic } \\
\text { sandstones, shales, } \\
\text { locally marls }\end{array}$ & $\begin{array}{l}\text { Książkiewicz (1977); } \\
\text { Uchman (1991c, } \\
\text { 1998); this study }\end{array}$ \\
\hline $\begin{array}{l}\text { "Zumaya Flysch", Basque } \\
\text { Country, Spain }\end{array}$ & No data & $\begin{array}{l}\text { Upper } \\
\text { Cretaceous - } \\
\text { lower Eocene }\end{array}$ & $\begin{array}{l}\text { Deep-sea turbiditic } \\
\text { limestones, marls, } \\
\text { sandstones and } \\
\text { shales }\end{array}$ & $\begin{array}{l}\text { Cummings and } \\
\text { Hodgson }(2011)^{*}\end{array}$ \\
\hline $\begin{array}{l}\text { Upper Istebna Beds, Silesian } \\
\text { Nappe, Carpathians, Poland }\end{array}$ & $\begin{array}{l}\text { Kamesznica (the stream } \\
\text { Janoska) }\end{array}$ & Paleocene & $\begin{array}{l}\text { Deep-sea turbiditic } \\
\text { sandstones and } \\
\text { shales }\end{array}$ & Książkiewicz (1977) \\
\hline $\begin{array}{l}\text { Kanina Beds, Magura } \\
\text { Nappe, Carpathians, Poland }\end{array}$ & Lubomierz & Paleocene & $\begin{array}{l}\text { Deep-sea turbiditic } \\
\text { marls and shales }\end{array}$ & $\begin{array}{l}\text { Cieszkowski et al. } \\
(1992)\end{array}$ \\
\hline $\begin{array}{l}\text { Itzurun Formation, Basque } \\
\text { Country, Spain }\end{array}$ & Zumaya section & Paleocene & $\begin{array}{l}\text { Deep-sea turbiditic } \\
\text { Limestones, marls, } \\
\text { sandstones and } \\
\text { shales }\end{array}$ & Giannetti (2010) \\
\hline
\end{tabular}


TABLE 1 (continued).

\begin{tabular}{|c|c|c|c|c|}
\hline $\begin{array}{l}\text { Formation and general } \\
\text { location }\end{array}$ & Localities & Age & Facies & References \\
\hline $\begin{array}{l}\text { Pagliaro Formation, Ligurian } \\
\text { Domain, Northern } \\
\text { Apennines, Italy }\end{array}$ & $\begin{array}{l}\text { Pallavicino, Celio, Salata, } \\
\text { Cabella Ligure, Fubbiano, } \\
\text { Borassi }\end{array}$ & Paleocene & $\begin{array}{l}\text { Deep-sea turbiditic } \\
\text { sandstones, marls } \\
\text { and shales }\end{array}$ & $\begin{array}{l}\text { Uchman (2007a); this } \\
\text { study }\end{array}$ \\
\hline $\begin{array}{l}\text { Greifenstein Sandstone, } \\
\text { Wienerwald, Rhenodanubian } \\
\text { Flysch, Austria }\end{array}$ & $\begin{array}{l}\text { Hof bei Karsten, } \\
\text { Schleifsteinbruch }\end{array}$ & Eocene & $\begin{array}{l}\text { Deep-sea turbiditic } \\
\text { sandstones and } \\
\text { shales }\end{array}$ & $\begin{array}{l}\text { Abel (1935); Uchman } \\
\text { (1999); } \\
\text { Kern (1978) }\end{array}$ \\
\hline $\begin{array}{l}\text { Variegated Shale, Magura } \\
\text { Nappe, Carpathians, Poland }\end{array}$ & Wola Brzezińska & $\begin{array}{l}\text { Upper } \\
\text { Paleocene- } \\
\text { Upper Eocene }\end{array}$ & $\begin{array}{l}\text { Deep-sea shales } \\
\text { with turbiditic } \\
\text { sandstones }\end{array}$ & Książkiewicz (1977) \\
\hline $\begin{array}{l}\text { Szczawnica Formation, } \\
\text { Magura Nappe, Carpathians, } \\
\text { Poland }\end{array}$ & $\begin{array}{l}\text { Hałuszowa, Krościenko- } \\
\text { Łąkcica, Szczawnica, } \\
\text { Szlachtowa, Łomnica, } \\
\text { Wierchomla Mała, Łosie, } \\
\text { Jamne, Jaszcze, } \\
\text { Rzyczanów }\end{array}$ & $\begin{array}{l}\text { Upper } \\
\text { Paleocene- } \\
\text { Lower Eocene }\end{array}$ & $\begin{array}{l}\text { Deep-sea turbiditic } \\
\text { sandstones and } \\
\text { shales }\end{array}$ & $\begin{array}{l}\text { Książkiewicz (1977); } \\
\text { Uchman (1991c, } \\
\text { 1992a, 2008a); } \\
\text { Wetzel and Uchman } \\
\text { (1998); this study }\end{array}$ \\
\hline $\begin{array}{l}\text { Gurnigel Flysch, Fribourgian } \\
\text { Alps, Switzerland }\end{array}$ & $\begin{array}{l}\text { Seeligraben } \mathrm{n} \text {. } \\
\text { Gurnigelbad, Zollhaus }\end{array}$ & Upper Paleocene & $\begin{array}{l}\text { Deep-sea, pelagic } \\
\text { and hemipelagic } \\
\text { sediments }\end{array}$ & $\begin{array}{l}\text { Fischer-Ooster (1858); } \\
\text { Crimes et al. (1981), } \\
\text { Uchman (1998, figure } \\
26 B, C)\end{array}$ \\
\hline $\begin{array}{l}\text { Flysch del Grivó, Julian } \\
\text { Prealps, NE Italy }\end{array}$ & Clapp, Vernasso & $\begin{array}{l}\text { Upper } \\
\text { Paleocene- } \\
\text { Lower Eocene }\end{array}$ & $\begin{array}{l}\text { Deep-sea turbiditic } \\
\text { sandstones and } \\
\text { shales }\end{array}$ & $\begin{array}{l}\text { Tunis and Uchman } \\
(1993,1996)\end{array}$ \\
\hline $\begin{array}{l}\text { Beloveža Formation, Magura } \\
\text { Nappe, Carpathians, Poland }\end{array}$ & Sidzina, Zbludza & $\begin{array}{l}\text { Lower-Middle } \\
\text { Eocene }\end{array}$ & $\begin{array}{l}\text { Deep-sea turbiditic } \\
\text { sandstones and } \\
\text { shales }\end{array}$ & $\begin{array}{l}\text { Książkiewicz (1977); } \\
\text { this study }\end{array}$ \\
\hline $\begin{array}{l}\text { Hieroglyphic Beds, Magura } \\
\text { Nappe, Carpathians, Poland }\end{array}$ & Rajcza (?) & Eocene & $\begin{array}{l}\text { Deep-sea turbiditic } \\
\text { sandstones and } \\
\text { shales }\end{array}$ & Książkiewicz (1977) \\
\hline $\begin{array}{l}\text { Hieroglyphic Beds, Dukla } \\
\text { Nappe, Carpathians, Poland }\end{array}$ & Daliowa & Eocene & $\begin{array}{l}\text { Deep-sea turbiditic } \\
\text { sandstones and } \\
\text { shales }\end{array}$ & Książkiewicz (1977) \\
\hline $\begin{array}{l}\text { Piwniczna Sandstone } \\
\text { Member of the Magura } \\
\text { Formation, Carpathians, } \\
\text { Poland }\end{array}$ & Tylmanowa-Baszta & Lower Eocene & $\begin{array}{l}\text { Deep-sea Turbiditic } \\
\text { sandstones and } \\
\text { shales }\end{array}$ & This study \\
\hline $\begin{array}{l}\text { Bisericani Formation, } \\
\text { Marginal Folds Unit, Eastern } \\
\text { Carpathians, Romania }\end{array}$ & Mt. Geamana, Valea Corbu & Upper Eocene & Marls & Krejci-Graf (1936) \\
\hline $\begin{array}{l}\text { Numidian Flysch, Atlas, } \\
\text { Tunisia }\end{array}$ & Meloula-Tabarka & Upper Oligocene & $\begin{array}{l}\text { Thin-bedded } \\
\text { turbidites } \\
\text { interbedded with } \\
\text { light green } \\
\text { mudstones }\end{array}$ & Riahi et al. $(2014)^{*}$ \\
\hline $\begin{array}{l}\text { Middle Bhuban molasse } \\
\text { sediments of Mizoram, } \\
\text { Northeast India }\end{array}$ & No data & Miocene & $\begin{array}{l}\text { Intertidal to subtidal } \\
\text { clastics }\end{array}$ & $\begin{array}{l}\text { Rajkumar et al. } \\
(2012)^{\star \star}\end{array}$ \\
\hline
\end{tabular}

\section{Methods}

Organic matter and carbonate content was measured for 11 samples using LECO RC612 equipment. The samples were stepwise heated to (1) $110{ }^{\circ} \mathrm{C}$, (2) $450{ }^{\circ} \mathrm{C}$, and (3) $1100{ }^{\circ} \mathrm{C}$ and the cor- responding loss in weight was recorded. During step (1), water evaporates, during step (2) organic matter is burnt, and during step (3) carbonate decays. 


\section{SYSTEMATIC ICHNOLOGY}

Ichnogenus TUBULICHNIUM Książkiewicz, 1977

Type ichnospecies. Tubulichnium incertum Książkiewicz, 1977.

Emended diagnosis. Oblique to horizontal, unbranched, straight or slightly winding, blind ending, filled, or originally almost void but preserved collapsed tube, which may be slightly swollen and stacked in the middle part. It is lined with small, elongate mud pellets.

Remarks. The original diagnosis of the ichnogenus Tubulichnium by Książkiewicz (1977, p. 142) stating: "Void subhorizontal and horizontal tubes with lined walls" is too broad. It does not refer to pellets, which are considered the diagnostic feature. The presence of pellets is mentioned in the diagnosis of the ichnospecies Tubulichnium incertum Książkiewicz, 1977. Therefore, the ichnogenus diagnosis is emended.

Tubulichnium rectum (Fischer-Ooster, 1858) comb. nov.

Figures 2.1-6, 3.1-7, 4.1-11, 5.1-8

*v. 1858 Halymenites rectus F.O. - FischerOoster, 55, pl. 13, fig. 2. [also in Uchman, 1998, fig. 25B.]

non v. 1858 Halymenites flexuosus F.O. - FischerOoster, 55, pl. 13, fig. 1. [(Transferred to Halymenidium Schimper by Schimper in Schimper and Schenk, 1879, p. 37, p. 37]

partim v. 1858 Halymenites minor F.O. - FischerOoster, 56, 65, pl. 13, fig. 1. [Redrawn in Uchman, 1998, fig. 25C] (non 65, pl. 16, fig. 2). [(Transferred to Halymenidium Schimper by Schimper in Schimper and Schenk, 1879, p. 37]

v. 1858 Halymenites incrassatus F.O. Fischer-Ooster, p. 65, pl. 16, fig. 3. [also in Uchman, 1998, fig. 25A]

non v. 1858 Halymenites dubius F.O. - FischerOoster, 66, pl. 12, fig. 4.

? $1863 \quad$ Halymenites rectus, H. flexuosus und H. minor F. O. - Ettingshausen, p. 461. [Not illustrated]

1909 Granularia cf. arcuata Schimp. - Reis, pl. 17, figs. 2-4. [Specimen in fig. 2 also in Häntzschel, 1975, p. W65, fig. 40.3a, under the same name]

1935 agglutinierte Wohnröhre - Abel, figs. 395, 396.

1936 Großer Fukoid .... - Krejci-Graf, 312, fig. 5.

non

1942 Agglutinierende Polychäten (Terebellinen) - Papp, figs. 1-3.
1959 Mit ellipsodischen Kotpillen austapezierter Gang - Seilacher, tab. 3.52.

v. 1977 Tubulichnium incertum n. ichnosp. Książkiewicz, p. 143, pl. 11, figs. 14, 15. [For fig. 15 see also Uchman, 2008c, text-fig. 29]

$\begin{array}{lll} & 1978 & \text { ?Granularia - Kern, 255, fig. 10A. } \\ \text { partim } & 1981 & \text { Granularia sp. - Crimes et al., p. 969, }\end{array}$ pl. 2, fig. 5 (non pl. 4, fig. 4).

v. 1991a Tubulichnium incertum - Uchman, p. 289, fig. 2A.

v. 1991c Tubulichnium incertum Książk. - Uchman, 209. [Not illustrated]

v. 1992 Tubulichnium incertum - Cieszkowski et al., p. 94. [Not illustrated]

v. 1992a Tubulichnium incertum - Uchman, p. 55 [Not illustrated].

v. 1993 Tubulichnium incertum Książkiewicz Tunis and Uchman, p. 87. [Not illustrated]

v. 1996 Tubulichnium incertum Książkiewicz Tunis and Uchman, p. 177, fig. 3J.

v. 1998 Ophiomorpha rectus (Fischer-Ooster, 1858) - Uchman, 126, figs. 25, 26.

v. 1998 "Tubulichnium incertum" Książkiewicz - Wetzel and Uchman, p. 537, fig. 5.

v. 1999 Ophiomorpha recta (Fischer-Ooster, 1858) - Uchman, 104, pl. 11, figs. 1, 2.

2004 Ophiomorpha rectus (Fischer-Ooster, 1858) - Leszczyński, p. 45, fig. 20.

v. 2007a Ophiomorpha recta (Fischer-Ooster, 1858) - Uchman, 224, pl. 2, fig. 1.

v. 2007b Ophiomorpha recta (Fischer-Ooster, 1858) - Uchman, 989, figs. 4B-C, 5B.

v. $2007 \quad$ Ophiomorpha recta - Wetzel et al., p. 573, fig. 7.

2007 Muensteria - Seilacher, pl. 72.

v. 2008a Ophiomorpha recta - Uchman, 121, fig. B6.2.C.

v. 2009 Ophiomorpha recta (Fischer-Ooster, 1858) - Uchman, 50, fig. 46.

2010 Ophiomorpha rectus - Giannetti, 110. [Not illustrated]

? $2011 \quad$ Ophiomorpha recta - Cummings and Hodgson, 173, pl. 1A.

non? 2012 Ophiomorpha rectus Fischer-Ooster, 1858 - Rajkumar et al., p. 71, fig. 2K.

v. ? $2014 \quad$ "Ophiomorpha" recta (Fischer-Ooster, 1858) - Riahi et al., p. 161, fig. 7D, E.

non 2014 Ophiomorpha cf. recta - Knaust et al., p. 2237, fig. 12D.

v. 2017b "Ophiomorpha" recta (Fischer-Ooster) - Uchman and Rattazzi, fig. 8C.

Diagnosis. Oblique to horizontal, unbranched, straight or slightly winding, blind ending, commonly 

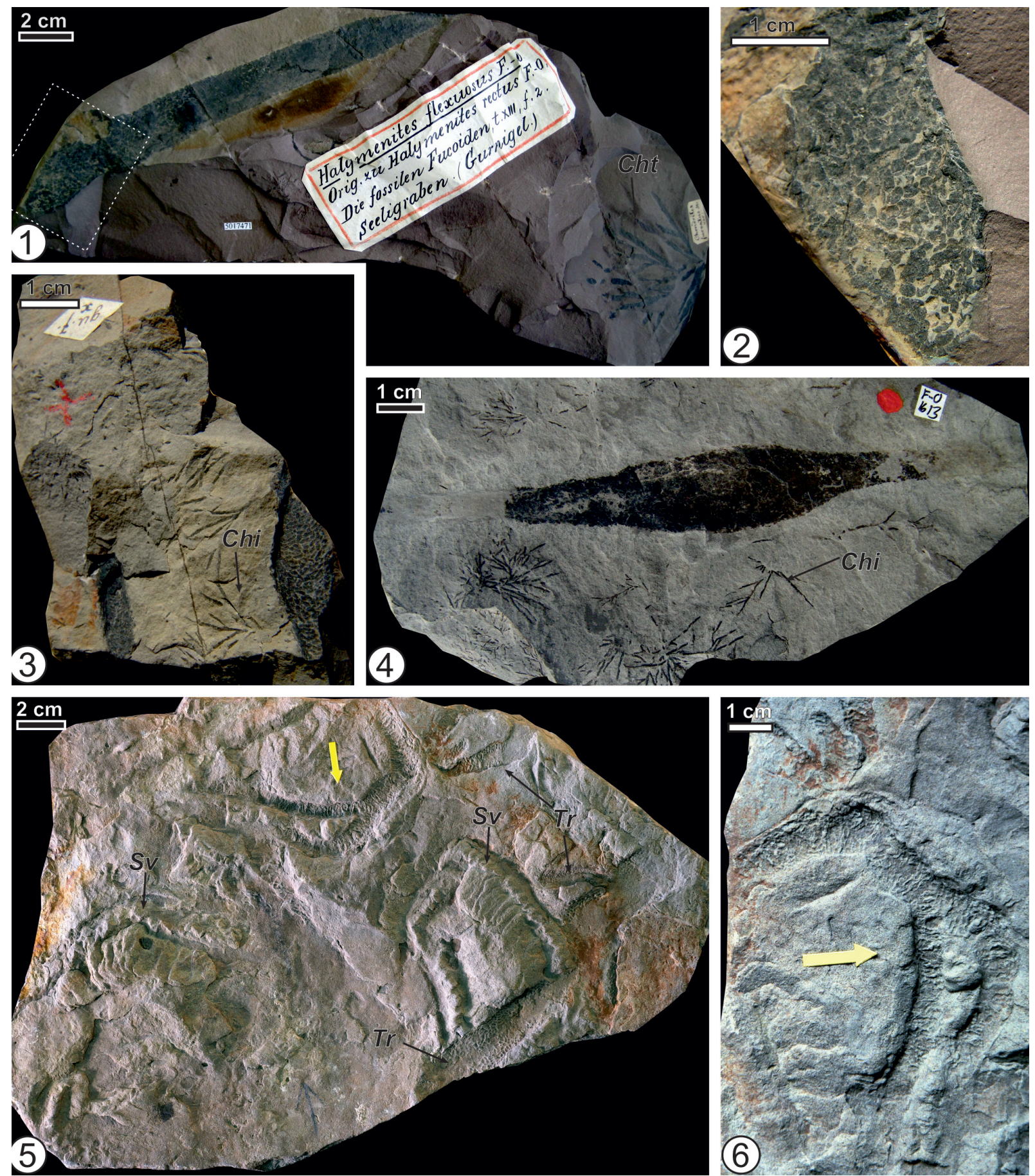

FIGURE 2. Holotype of Tubulichnium rectum (Fischer-Ooster, 1858) and some other key specimens described by Fischer-Ooster (1858) and Książkiewicz (1977), which are housed in the Naturhistorisches Museum der Burgergemeinde Bern (NMBE) in Switzerland and in the Nature Education Centre of the Jagiellonian University - Museum of Geology, Kraków, Poland, respectively: 1, holotype, originally Halymenites rectus Fischer-Ooster and Chondrites targionii (Cht), Gurnigel Flysch (Maastrichtian), Seeligraben near Gurnigelbad (Switzerland), specimen NMBE 5017471. Detail illustrated in 2 marked by the quadrangle; 2, detail of 1; 3, original of Halymenites minor Fischer-Ooster, 1858 and Chondrites intricatus (Chi) from Gurnigel Flysch (Maastrichtian), Seeligraben near Gurnigelbad (Switzerland), specimen NMBE 5017474; 4, original of Halymenites incrassatus Fischer-Ooster, 1858, Fähnernspitz, Upper Cretaceous, E Switzerland, specimen NMBE 5017470; 5, holotype of Tubulichnium incertum Książkiewicz, 1977 (yellow arrow), other specimen of the same ichnotaxon ( $T r$ ) and Scolicia vertebralis (Sv); Ropianka Formation (Inoceramian Beds), Upper Cretaceous-Paleocene, Bachów, Skole Nappe, specimen UJTF 938; 6, detail of 5 showing the holotype. 

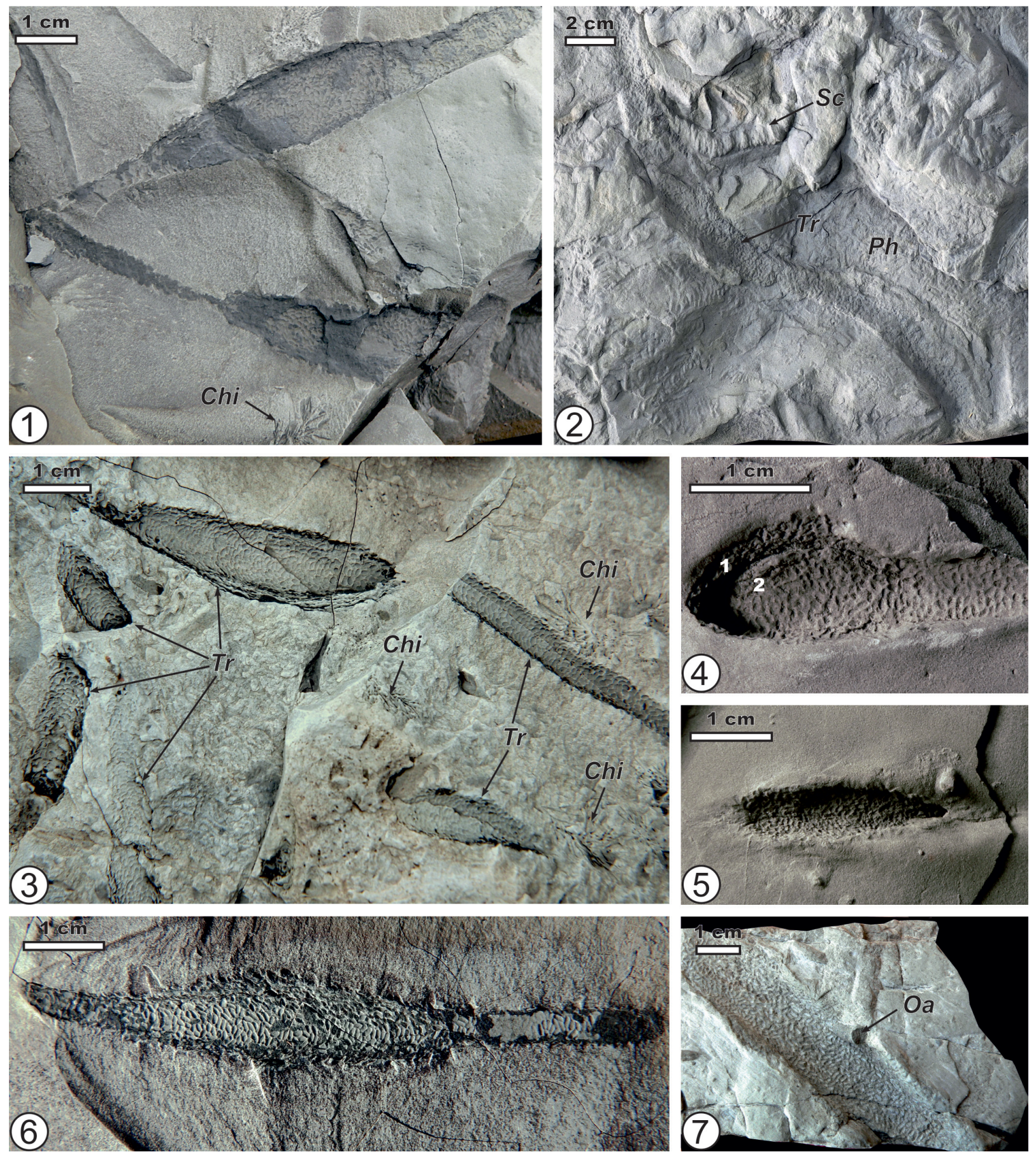

FIGURE 3. Tubulichnium rectum (Fischer-Ooster, 1858) on upper bedding surfaces from different formations: 1, on the upper surface of turbiditic marl with Chondrites intricatus (Chi), Pagliaro Formation (Paleocene), Cabella Ligure, Northern Apennines, Italy, field photograph; 2, curved example of T. rectum (Tr), Scolicia isp. (Sc) and Phycosiphon incertum (Ph), Ropianka Formation (Upper Cretaceous), Wara, Skole Nappe, Carpathians, Poland, UJTF 1426, Książkiewicz collection; 3, several specimens of $T$. rectum $(T r)$, some cross cut by Chondrites intricatus (Chi), Pagliaro Formation (Paleocene), Cabella Ligure, Northern Apennines, Italy, field photograph; 4, specimen with two (1, 2) superimposed pellet pavements. Inoceramian Beds (Upper Cretaceous-Paleocene), Słopnice, INGUJ144P190a; 5; specimens with elevated edges and collapsed roof, Inoceramian Beds (Upper Cretaceous-Paleocene), Słopnice, INGUJ144P140; 6, example of spindle-shaped burrow enlargement, Pagliaro Formation (Paleocene), Cabella Ligure, Northern Apennines, Italy, field photograph; 7, T. rectum cut by Ophiomorpha annulata (Oa), Inoceramian Beds (Upper Cretaceous-Paleocene), Słopnice, INGUJ143P66. 

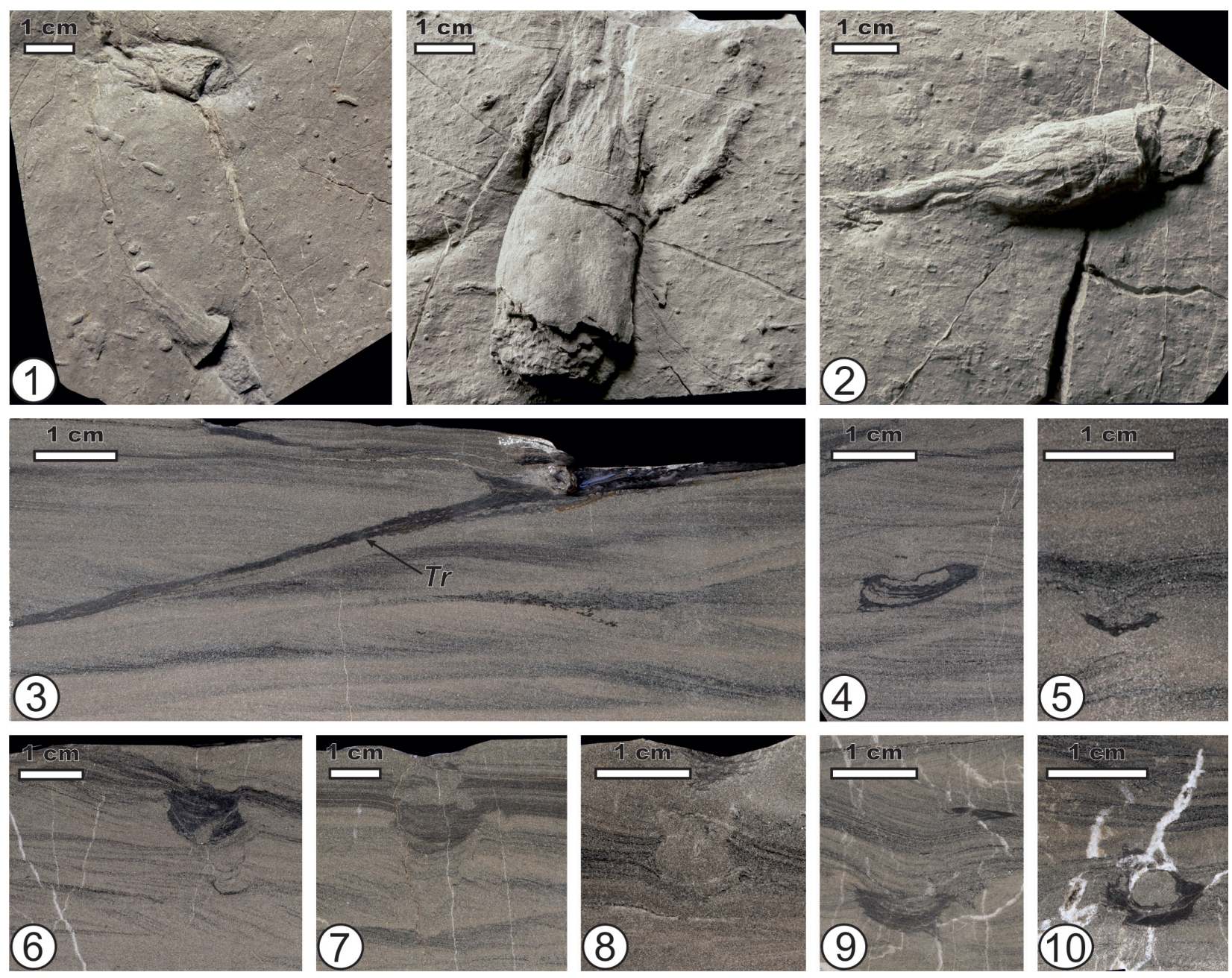

FIGURE 4. Tubulichnium rectum (Fischer-Ooster, 1858) on the lower bedding surfaces (1-3) of and in longitudinal (4) and transverse (5-10) cross-sections of turbiditic sandstones from the Inoceramian Beds (Upper-Cretaceous-Paleocene) at Słopnice: 1, note external and internal parts INGUJ144P176; 2, note sandy mantle covering the pelleted part, INGUJ144P193a, 3, note wrinkles on the mantle, INGUJ144P187a; 4, longitudinal cross section (Tr), INGUJ144P193; 5-10, transverse sections, E - INGUJ144P182d, F - INGUJ144P180, G - INGUJ144P192b, H - INGUJ144P170a, I INGUJ144P190, J - INGUJ144P192c, K - INGUJ144P192.

originally almost void but preserved collapsed tube, which may by slightly swollen in the middle part. It is lined with small, elongated muddy pellets.

Holotype. Specimen NMBE 5017471, Naturhistorisches Museum der Burgergemeinde Bern (Switzerland), labelled as "Halymenites flexuosus F.O. Die fossilien Fucoiden, t. XIII, f. 2, Orig. zu Halymenites flexuosus F.O. Seeligraben (Gurnigel.)," illustrated by Fischer-Ooster (1858, p. 55, plate 13, figure 2). Figure 2.1-2 in this paper.

Other specimens. Naturhistorisches Museum der Burgergemeinde Bern (Switzerland): 1) specimen NMBE 5017470 - original of Halymenites incrassatus Fischer-Ooster, 1858, Fähnernspitz, E Switzerland (Figure 2.4); 2) specimen NMBE 5017474 original of Halymenites minor Fischer-Ooster,
1858, Seeligraben, Gurnigelbad, Switzerland (Figure 2.3).

Institute of Geological Sciences, Jagiellonian University, Kraków, Poland: 1) 28 specimens from the Słopnice section, the Inoceramian Beds, Magura Nappe, Carpathians, Poland (INGUJ143P42, 66, 74, INGUJ144P170-180, 182$195) ; 2)$ one slab from the old quarry at Krzeczkowa, Holovnia Marl, Skole Nappe, Carpathians, Poland (INGUJ193P140); 3) one specimen from the Szczawnica Formation at Łąkcica (INGUJ144P99), three specimens from the same formation at Jamne (INGUJ143P84, 86, 87) and one from Jaszcze (INGUJ143P85); 4) one specimen from the Piwniczna Sandstone Member of the Magura Formation (Lower Eocene) at Tylmanowa- 

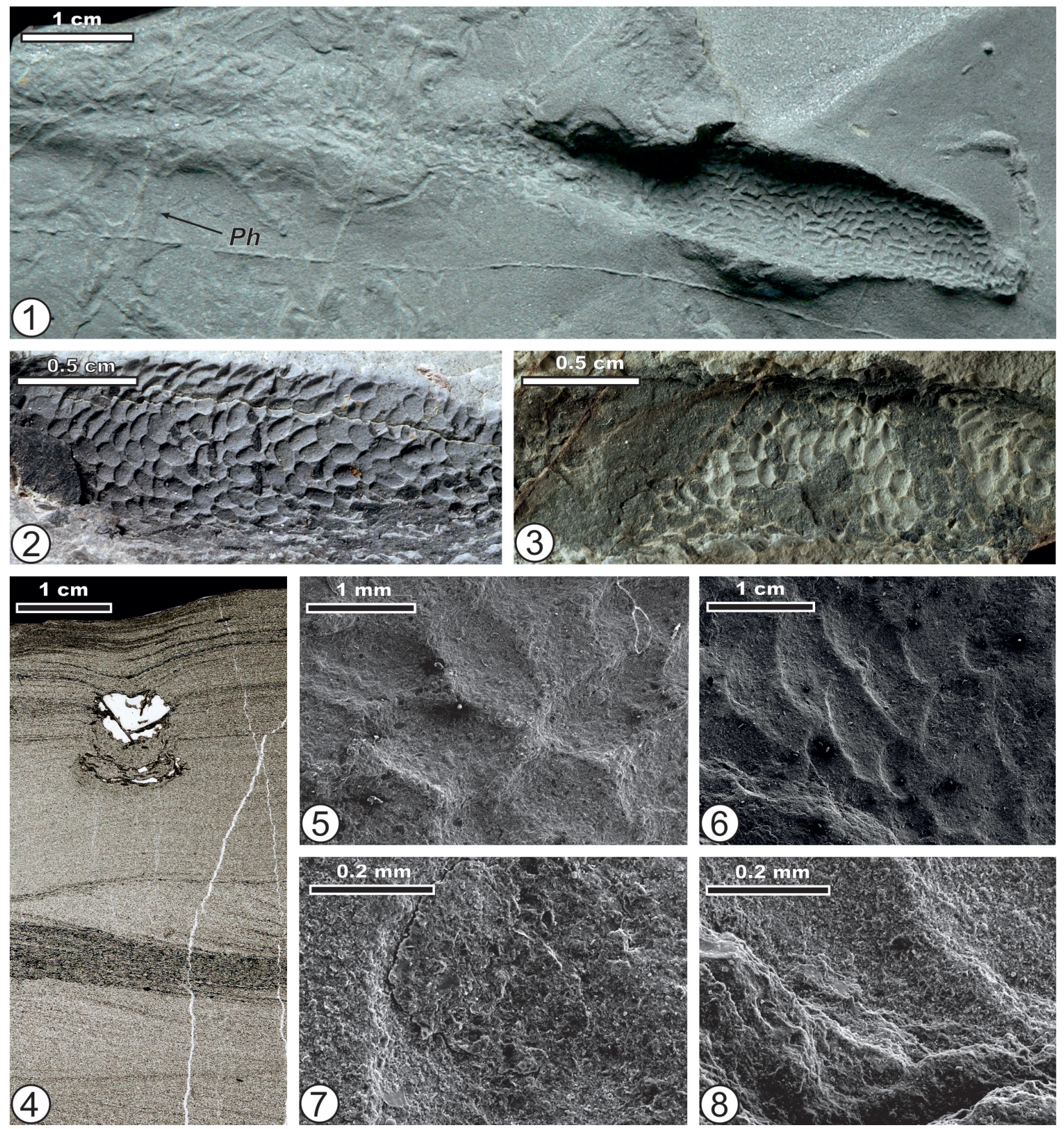

FIGURE 5. Macroscopic and microscopic and SEM observations of Tubulichnium rectum (Fischer-Ooster, 1858) occurring in turbiditic sandstones of the Inoceramian Beds (Upper Cretaceous-Paleocene), Stopnice, Poland (1, 4-8) and turbiditic marls of the Pagliaro Formation (Paleocene), Italy $(2,3): \mathbf{1}$, specimen with elevated edges and bent down roof as seen on upper bedding surface (INGUJ144P195); 2, 3, depressions of pellets in the burrow margin after pellets have been partly or completely removed (INGUJ196P36 and 38); 4, photomicrograph of transverse cross-section; note deformed laminae above the collapsed burrow; 5, 6, burrow margin showing depressions of pellets that have been removed by weathering; 7 , part of split pellets in place consisting of clay minerals and siliciclastic silt grains; $\mathbf{8}$, outer part of a split pellet showing platy minerals oriented \pm parallel to surface. 
Baszta (INGUJ144P140); 5) 10 specimens from the Pagliaro Formation (Paleocene) at Cabella Ligure, Northern Apennines, Italy (INGUJ149P11b, 13; INGUJ149P35-41) and Celio (INGUJ149P42); 6) three specimens from the Gurnigel Flysch, Paleocene, from Seeligraben (INGUJ154P100, 102) and from the Zollhaus Quarry (INGUJ154P101).

The Nature Education Centre of the Jagiellonian University (CEP) - Museum of Geology, six slabs in the Książkiewicz collection: 1) Skole Nappe, Inoceramian (Ropianka Beds) at Bachów (UJ TF 938 - the holotype of Tubulichnium incertum Książkiewicz, 1977; Figure 2.5-6) and Wara (UJ TF 1426 - Figure 3.2; UJ TF 1434); 2) Magura Nappe, Inoceramian (Ropianka Beds) at Wola Brzezińska (UJ TF 1026) and Berest (UJ TF 856, 1844).

Crocefischi Museo, Crocefieschi N of Genova, Italy: three specimens 5008, 5214, 6444 from the Pagliaro Formation (Paleocene) at Salata.

Naturhistorisches Museum in Vienna, Austria, two specimens (without numbers): 1) one specimen from the Greifenstein Sandstone, Greifenstein quarry, Wienerwald, Rhenodanubian Flysch, Austria (collected in 1908); 2) one specimen from the Inoceramian Beds, Skole (Skyba) Nappe, Dora (Yaremche), Ukraine.

The Bavarian Natural History Collections (Staatliche Naturwissenschaftliche Sammlungen Bayerns, SNSB): one specimen PIW1993X221, Flysch del Grivó (Paleocene-Eocene) at Clapp, Friuli, Italy.

Description. Inclined to horizontal, strongly flattened, blind ending tubes, observed usually in the upper part of sandy beds. The tubes are 2-22 $\mathrm{mm}$ wide, in maximum $215 \mathrm{~mm}$ long. Usually, only a short segment of the trace is observed because the remaining part is plunging into the bed. The width of the tube changes along its course exhibiting usually one spindle- shaped swelling in the middle (Figures 2.4, 3.1, 3.6). Two swellings are very rare. The swellings are up to $6.5-15 \mathrm{~mm}$, rarely up to 29 $\mathrm{mm}$, wide. The holotype is $172 \mathrm{~mm}$ long and 14$20.5 \mathrm{~mm}$ wide, but is limited by the edges of the slab.

Most of the tubes are straight. Curved tubes are rare (Figures 2.5-6, 3.2). The interior tube margin is covered with small, elongate mud pellets, which are 0.7-2 mm long and 0.7-1 $\mathrm{mm}$ wide. When the pellets are removed or weathered, the burrow margin shows scalloped depressions, which are elliptical, half-elliptical, or crescent in outline, $0.5-1.2 \mathrm{~mm}$ long, and up to $0.8 \mathrm{~mm}$ wide
(Figure 5.1-3, 5.5-8). If the pellets are densely packed, the depressions tend to form an irregular, elongated meshwork, with straight or slightly curved bordering crests. The pellets are composed of clay and fine silt grains and most of them are less than $10 \mu \mathrm{m}$ in size. Close to the surface of the pellets, mineral flakes can be parallel or subparallel to the pellet surface.

In transverse cross-section, the burrow geometry shows some variability (Figures 4.5-11, 5.4). It can be irregularly elliptical, sub-angular, trapezoid, wedge-shaped, or bent-down bar-like in outline. Width is usually larger than height, but inverse cases may occur. Occasionally if the height of the burrow exceeds its width, the lower part is narrower than the middle and upper part. The lower part of the burrow fill is usually muddy and the upper enriched in sand. In many transverse crosssections, spreite-like lamination is present, usually bending down in the central part. The laminae can be underlined by a muddy or sandy film. Terminations of the laminae are uneven, occasionally splitting. Therefore, in cross-section the tube sides appear in many cases uneven. Rarely, the mantle is sandy (Figure 4.9). In some cases, a sandy core wrapped partly, or rarely completely, by a muddy mantle is seen (Figure 4.11).

The burrows are horizontal or nearly horizontal for most of their course, or they dip into the beds at a more or less constant angle ranging from $15^{\circ}$ to $27^{\circ}$ (Figure 4.4). Some burrows pierce a bed and occur on the lower side as inclined tubes with a sandy mantle, which can be covered by longitudinal wrinkles (Figure 4.1-3). Laminae within the bed are slightly bent down at the sides of the burrow for a distance of 1-3 $\mathrm{mm}$. The laminae above the burrow are commonly bent down probably due to collapse of the causative tube after abandonment (Figures 4.6, 4.10, 5.1). Edges of some burrows are elevated (Figure 5.1).

Remarks. Tubulichnium rectum occurs in very fine and fine-grained calcareous sandstone, sandy marl, or marl beds of variable thickness. They are of turbiditic origin and interbedded with pelagic/ hemipelagic, calcareous, or non-calcareous mudstones (Figure 6).

Tubulichnium rectum co-occurs in the same bed with Scolicia vertebralis Książkiewicz and Phycosiphon incertum Fischer-Ooster (see Książkiewicz, 1977, p. 143), Chondrites intricatus (Brongniart), C. targionii (Brongniart), C. affinis (Sternberg), Lophoctenium ramosum (Toula), Nereites irregularis (Schafhäutl), Zoophycos isp., Ophiomorpha annulata (Książkiewicz), Planolites 

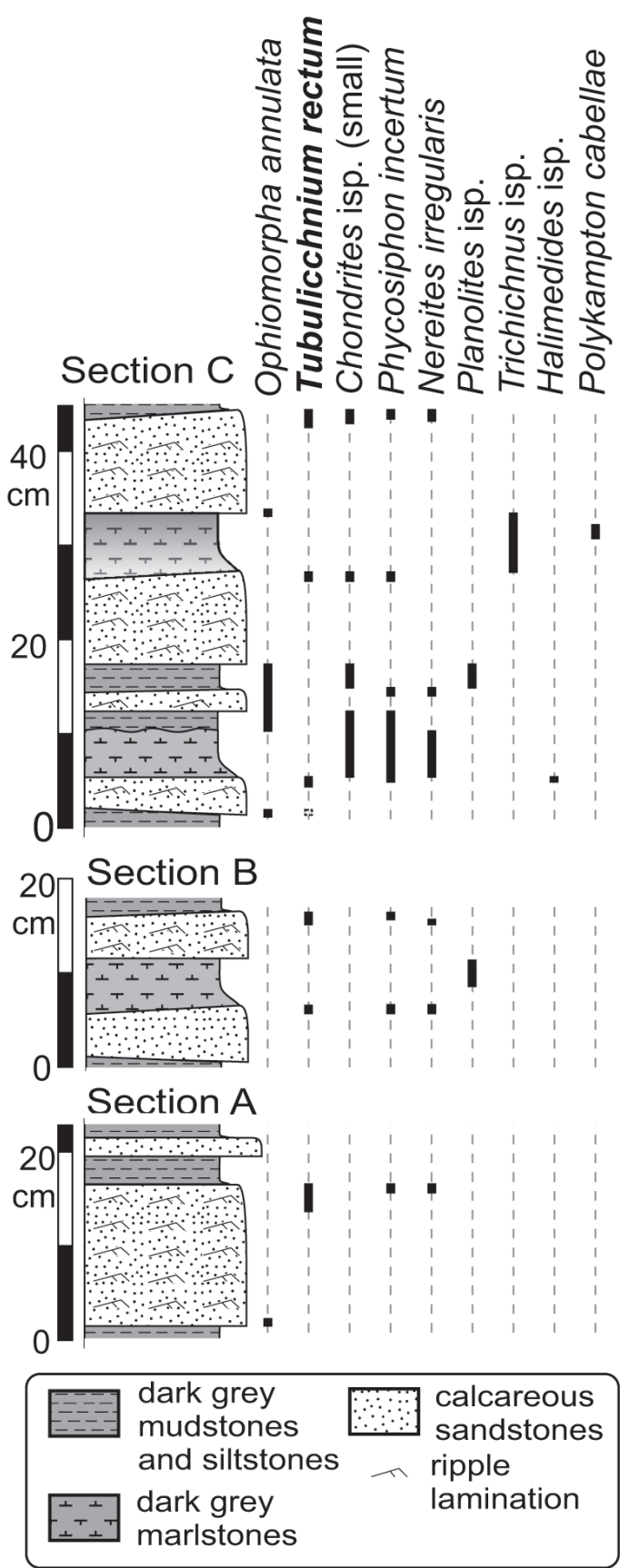

FIGURE 6. Short sections showing position of Tubulichnium rectum and associated traces fossils in strata of the Ropianka Formation (Inoceramian Beds) at Słopnice, Magura Nappe, Carpathians, Poland. GPS coordinates: section $\mathrm{A}: 49^{\circ} 42.982^{\prime} \mathrm{N}, 020^{\circ} 20.448^{\prime} \mathrm{E}$; section $\mathrm{B}$ : $49^{\circ} 42.974^{\prime} \mathrm{N}, \quad 20^{\circ} 20.453^{\prime} \mathrm{E}$, section C: $49^{\circ} 42.610^{\prime} \mathrm{N}$, $20^{\circ} 20.687^{\prime} \mathrm{E}$.

isp., Taenidium isp., Trichichnus isp., Polykampton cabellae Uchman and Rattazzi, Phycosiphon geniculatum (von Sternberg), "Rhizocorallium" hamatum (Fisher-Ooster), Acanthorhaphe isp. and Megagrapton isp. Some specimens are cross cut by $O$. annulata, C. intricatus, Ph. incertum, and some unidentified tubular burrows. In some beds, $T$. rectum penetrates $S$. vertebralis, $N$. irregularis, C. intricatus, and C. targionii.

\section{DISCUSSION}

\section{Ichnotaxonomic Problems}

Originally, the presented trace fossil was described as an alga under the genus Halymenites von Sternberg, 1833. As the first species, FischerOoster (1858) established Halymenites rectus Fischer-Ooster, 1858, which should be considered as the type ichnospecies by page priority. Furthermore, Fischer-Ooster (1858) distinguished Halymenites flexuosus, $H$. minor, $H$. incrassatus, and $H$. dubius. The latter was described in the same publication as Chondrites dubius (p. 54), but transferred to Halymenites on page 65 . This trace fossil shows branches and is dissimilar to the Halymenites ichnospecies. The original diagnosis of Halymenites rectus by Fischer-Ooster (1858, p. 55) states: "Halymenites fronde plana recta simplici latitudinem fere pollicarem attingente, sporangis ovatris lineam metientibus replete." It can be translated as: "Halymenites with foliage [being] plane, straight, simple, [so] dense that nearly touching at the long side, filled up with ovate sporangia having a line in the length." Very likely the whole tube was interpreted by Fischer-Ooster as foliage (at another place he describes it as a stem), whereas the pellets were interpreted to represent sporangia.

Schimper in Schimper and Schenk (1879, p. 37) stated that Halymenites Sternberg, 1833 is a very problematic genus. Therefore, he erected a new genus Halymenidium in which he included, according to the order in the text, Halymenites flexuosus Fischer-Ooster, 1858, Halymenites minor Fischer-Ooster, 1858, Halymenites lumbricoides Heer, 1865 and Phymatoderma dienvalii Watelet, 1866. Indeed, the original species of Halymenites published by von Sternberg, 1833 are Jurassic plants from Solnhofen in Germany (Häntzschel, 1962) and cannot be used for ichnotaxonomic purposes (Uchman, 1998). Halymenidium Schimper, however, is also problematic, because the aforementioned taxa included in Halymenidium represent different ichnogenera, including the first taxon accounted by Schimper, i.e., Halymenites flexuosus Fischer-Ooster, 1858. The original material of $H$. flexuosus is not present among the other ichnospecies of Halymenites in the Museum in Bern (U. Menkveld-Gfeller, 2016, personal communication). Judging from the drawing by Fischer-Ooster, 1858 
(plate 13, figure 1), this trace fossil is composed of a stem and side branches containing small pellets arranged perpendicular to the stem and branches. It resembles better Phymatoderma Brongniart, 1849 than the discussed trace fossil (for Phymatoderma see $\mathrm{Fu}, 1991)$. Phymatoderma dinevalli Watelet, 1866, the other species included in Halymenidium by Schimper, is in fact a synonym of Ophiomorpha nodosa Lundgren, 1891 (Häntzschel, 1952). Halymenites lumbricoides Heer, 1865 was included in Alcyonidiopsis longobardiae Massalongo, 1856 by Chamberlain (1977). Therefore, Halymenidium Schimper is not recommended for further use (Uchman, 1998).

Häntzschel (1952) noticed that Halymenidium rectum (Fischer-Ooster) and $H$. incrassatum (Fischer-Ooster) differ from Ophiomorpha Lundgren, 1891 by the straight course and smaller diameter and thus, they cannot be synonymized. However, Häntzschel (1962, p. 206) included Halymenidium Schimper in Ophiomorpha with a question mark. Also Vialov (1966) included reservedly Halymenites rectus Fischer-Ooster, 1858, $H$. incrassatus Fischer-Ooster, 1858 and $H$. flexuosus Fischer-Ooster, 1858 in Ophiomorpha. This suggestion was adopted by Uchman (1998), who emphasized the pelletal lining as the principle morphological feature and proposed a new combination; Ophiomorpha rectus (Fischer-Ooster, 1858) corrected by Uchman (1999, 2007b) as Ophiomorpha recta (Fischer-Ooster, 1858). After studying numerous specimens of this trace fossil, the assignment to Ophiomorpha should be considered as unfortunate, because: 1) Ophiomorpha, typified by $O$. nodosa Lundgren, 1891 (for this ichnogenus and ichnospecies see Frey et al., 1978, 1984) is a branched burrow, whereas $O$. recta is unbranched, and 2) $O$. nodosa shows a constructed wall composed of relatively large pellets, circular in outline and built of muddy sandstone, whereas $O$. recta does not have a constructed wall, only a local mantle that may be present, and its pellets are relatively small, elliptical in outline, and consist of mud.

The discussed trace fossil was also described by Reis (1909) as Granularia Pomel, 1849 (the same Häntzschel, 1975), but Granularia is not recommended for further use (Uchman, 1995). Seilacher (2007) illustrated the trace fossil as Muensteria Sternberg, 1833, but also this ichnogenus is not recommended for further use (Mikuláš and Uchman, 1996).

For the discussed trace fossil, Książkiewicz (1977) erected a new ichnogenus and ichnospecies Tubulichnium incertum Książkiewicz, 1977.
Due to taxonomic situation outline above, Tubulichnium is considered as the valid, proper ichnogenus name, but the ichnospecies name should be taken from Halymenites rectus Fischer-Ooster, 1858. Therefore, the new combination Tubulichnium rectum (Fischer-Ooster, 1858) is proposed. The holotype of Tubulichnium incertum Książkiewicz, 1977 is a rather atypical example of $T$. rectum, because it is represented by two curved overlapping burrows (Figure 2.5-6). Nevertheless, on the same slab, a straight, but less complete, burrow is present. Moreover, other specimens in the Książkiewicz collections, labelled as Tubulichnium incertum, are typical $T$. rectum. Therefore, there are no doubts that $\mathrm{M}$. Książkiewicz considered all of them as belonging to the same ichnotaxon.

Cummings and Hodgson (2011, figure 1A) recorded "Ophiomorpha recta" in fringe, fan fringebasin floor, basin floor transition and lobe-off axis facies in Palaeogene flysch of northern Spain, but the only illustration of this trace fossil is a hypichnial full relief, which makes inclusion into Tubulichnium rectum problematic (see the synonymy list).

Tubotomaculum García-Ramos et al., 2014, typified by $T$. mediterranensis García-Ramos et al., 2014, from the Upper Cretaceous-Miocene deepsea deposits of the Mediterranean region displays the same basic morphological pattern: unbranched form, spindle widening, elongate pellets present in the external parts, and a teichichnoidal shift of the causative tube. This shift is more extensive than in Tubulichnium rectum and Tubotomaculum is typically mineralized. Nevertheless, the differences should be considered as insignificant at the ichnogenus level and, therefore, Tubotomaculum García-Ramos et al., 2014 should be considered as a junior synonym of Tubulichnium Książkiewicz, 1977, with conservation of $T$. mediterranensis as a separate ichnospecies.

Ophiomorpha puerlis Gibert et al., 2006 is a simple, cylindrical, mostly vertical burrow, 1.6-3.3 $\mathrm{mm}$ in diameter, associated with Ophiomorpha nodosa Lundgren, 1891. It displays a wall built of subcylindrical pellets. Because of the pellets and unbranched morphology, this trace fossil resembles Tubulichnium, but it displays a constructed wall, similar to Ophiomorpha nodosa. Moreover, its vertical orientation and close association with Ophiomorpha strongly suggest their taxonomic separation. 


\section{Trace Maker and Ethological Interpretation}

Originally, Halymenites rectus (now Tubulichnium rectum) was regarded as a fucoid alga (Fischer-Ooster, 1858). Reis (1909) reinterpreted it as worm burrow. Abel (1935) interpreted Tubulichnium rectum (his "agglutinierte Wohnröhre") as a dwelling trace of a tubiculous worm. Książkiewicz $(1977$, p. 19, 144) considered it as a post-depositional "feeding burrow which could serve as temporary or permanent shelter" produced by crustaceans. Also Crimes et al. (1981) regarded that such burrows (their Granularia) are produced by crustaceans. Uchman (1991, 1992b) considered Tubulichnium rectum (Halymenites in the cited publications) as an opportunistic trace fossil. Wetzel and Uchman (1998) noticed its deep-tier position and connection to the sea floor.

The unbranched pattern, the swellings and the constriction of the tunnel at both ends suggests a soft-bodied "worm"-like organism, which was able to change the width of its body. Furthermore, the pellets pressed into the lining, deformed laminae around the lower part of the burrow and within the external part of the filling suggest that the trace maker was able to compress the sediment. The spreite-like basal part documents a long occupation of the burrow, with sediment that was occasionally introduced into the burrow being compressed at the base of the tube.

The ellipsoidal muddy pellets, usually less than a millimetre long, are very similar to those found in Rhizocorallium, Zoophycos, Phymatoderma, and Ophiomorpha puerilis (Izumi, 2013; Knaust, 2013; Uchman and Rattazzi, 2017a; Netto et al., 2017). If isolated, they are usually described as Coprulus oblongus Mayer, 1952 and referred to the ichnofamily Coprulidae (see Knaust, 2008). Knaust (2013) noticed in his revision of Rhizocorallium that such pellets suggest a common producer, possibly a polychaete. Indeed, most ellipsoidal pellets are produced by polychaetes (e.g., Kraeuter and Haven, 1970; Kulkarni and Panchang, 2015). However, echiurans can produce similar pellets (Popkov, 1992; Biseswar, 2005), as well as enteropneusts (Thomas, 1972) and sipunculids (Jumars et al., 1990). In addition, some sipunculids may construct a cache while shifting the causative tube in its deepest part vertically (Jumars et al., 1990, figure 1). Therefore, a closer determination of the "worm" producers is not possible.

Tubulichnium rectum occupies a relatively deep tier. In the Ropianka Formation, it crosses up to $6.5 \mathrm{~cm}$ thick sandstone beds and in the Pagliaro Formation it penetrates $3-5 \mathrm{~cm}$ deep from the top of thick marl beds. In the latter case, Chondrites and Trichichnus are produced deeper in the sediment, similar to Ophiomorpha annulata in the Ropianka Formation (Figure 6). In cases that Tubulichnium rectum cross-cuts Chondrites, it is interpreted to have been produced in a late phase of colonization of a freshly accumulated turbidite, according to the model of sequential colonization by Wetzel and Uchman (2001). After deposition, content of oxygen in pore water and food in the turbidite decreases within a few years and thus, horizontal sediment reworking becomes an inappropriate nutritional strategy.

The pelleted filling of Tubulichnium rectum resulted from an active transfer of organic-rich material into a relatively deep tier. Compared to the host sediment containing $1.1 \pm 0.1 \%$ organic carbon and the overlying dark mud $\left(0.7 \pm 0.1 \% \mathrm{C}_{\text {org }}\right)$, the pelleted burrow fill is enriched in organic matter $\left(1.5 \pm 0.1 \% \mathrm{C}_{\text {org }}\right)$. Furthermore, the carbonate content of the pelleted fill $(20 \pm 1 \%)$ is higher than that of the (hemi)pelagic dark mud ( $12 \pm 2 \%$ ). The carbonate content of the turbiditic sandstones (26 $\pm 4 \%$ ) is of detrital origin and hence, not considered here. The enrichment of organic matter and carbonate within the pelleted fill implies that organic material and carbonate shells accumulating on the sea floor during bloom times were transferred into a burrow before organic and carbonate content decreased after bloom times due to oxidation of organic matter (e.g., Aller, 1994). The outlined scenario is supported by observations in the modern South China Sea; during blooms, not only large amounts of organic matter, but also carbonate shells, accumulate on the sea floor and both become degraded during non-bloom times (e.g., Wetzel, 2008, figure 9). Burrows of endobenthic organisms that ingest material deposited during bloom times contain carbonate shells even in settings below Calcite Compensation Depth (CCD), because carbonate dissolution is hindered within the burrows (Wetzel and Unverricht, 2013).

After feeding on nutritional mud on the surface, especially after the arrival of fresh organic matter, the trace maker packed organic-rich muddy pellets into its burrow within the oxygen-deficient host sediment at a depth beyond the range that shallowly burrowing sediment-feeders usually penetrate. During times of starvation, the burrow producer could feed on such sequestered material. Because of oxygen deficiency, organic matter was not subjected to rapid decomposition and was available as a food source for some time even if it was microbially fermented (e.g., Arndt et al., 2013). 
In fact, the burrow represented a sort of a nutritional cache, similar to the cache model of Zoophycos (Bromley, 1991). The food from the pellets can also be exploited indirectly, probably by solutions and ectoenzymes. There is no evidence of direct and repeated reworking, but the burrow was inhabitation by the producer for a long time. Microbial activity within the burrow fill is likely (e.g., Kristensen, 2000), but not easy to prove, as no microbial structures were observed.

Such a feeding strategy as proposed for Tubulichnium rectum is a good response to seasonal oligotrophy on the deep-sea floor, where nutritional quality of freshly-deposited organic matter deteriorates quickly by oxygenation and microbial decomposition. Modern examples from the South China Sea point to an intensive use of seasonally supplied organic-rich sediments sequestered in burrows as a food source (Wetzel, 2008). Such a strategy fits well to the new ethological category, sequestrichnia, as proposed by Uchman and Wetzel (2016). The success of the outlined nutritional strategy is illustrated by the relatively high density of $T$. rectum in some beds. For the top bed in section $C$ (Figure 6 ), it reaches about 50 burrows $/ \mathrm{m}^{2}$.

\section{Environmental Significance and Stratigraphic Range}

Tubulichnium rectum specimens have been reported to occur in Triassic to Paleogene, mainly turbiditic, occasionally calcareous sediments (Table 1). In clastic turbiditic deposits, T. rectum occurs mostly in thin- and medium-bedded, very fine or fine-grained calcareous strata, which commonly show cross bedding. Rarely, $T$. rectum was encountered at the top of up to $150 \mathrm{~cm}$ thick sandstone beds. In the Pagliaro Formation, T. rectum occurs at the top of up to $40 \mathrm{~cm}$ thick marls, which form the upper part of turbiditic sandstone-marl couplets. The marls are covered by dark grey, noncalcareous (hemi)pelagic mudstones. Similarly, in the Ropianka Formation, the overlying non-turbiditic mudstones can be free of carbonate. Consequently, accumulation of these deposits below the local CCD is highly likely. The producer of $T$. rectum appears to prefer distal depositional lobe, interlobe, fan fringe, and basin plain turbiditic facies as established in classic sand-rich deep-sea fan models (e.g., Mutti, 1992; Stow et al., 1996). The trace producer tolerated different substrates varying from fine sand to marly mud.

The associated trace fossils are typical of the Nereites ichnofacies, in particular the Paleodictyon

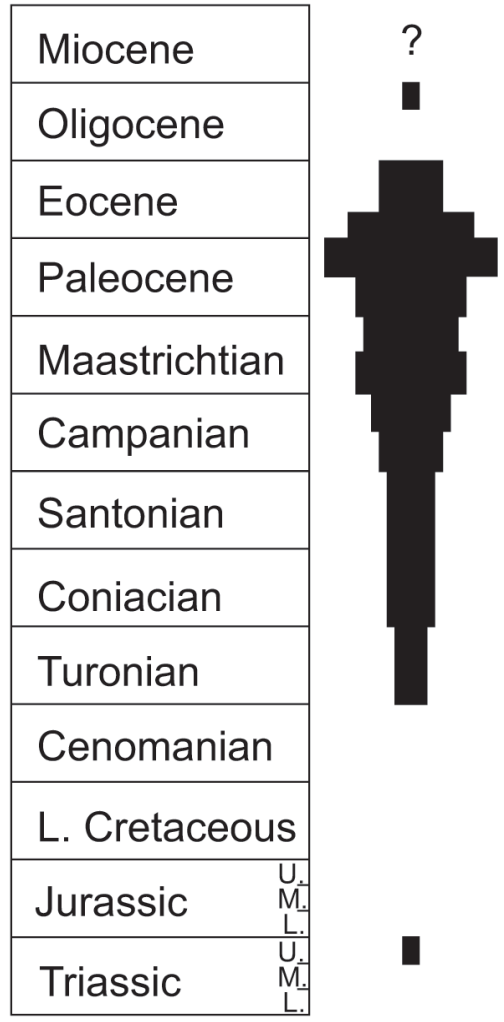

FIGURE 7. Stratigraphic range of Tubulichnium rectum (Fischer-Ooster, 1858) and number of formations per stage in which it occurs.

or Nereites subichnofacies, which may contain graphoglyptids or dominating Nereites and Phycosiphon, respectively (for details see Uchman and Wetzel, 2012). The occurrence of $T$. rectum in the Zoophycos ichnofacies appears to be possible, but any evidence is lacking so far.

An isolated Triassic occurrence is noted by Wetzel et al. (2007), which is related to an unusual high-diversity trace-fossil association. The trace fossil producers there were minimally affected by the severe ecologic conditions following the Permian-Triassic mass extinction (Wetzel et al., 2007). Tubulichnium rectum ranges continuously from the Turonian to Eocene (e.g., Książkiewicz, 1977; see also Figure 7 and Table 1). Tubulichnium rectum is more frequently recorded in Campanian to the middle Eocene strata, with an acme in the upper Paleocene. The isolated occurrence in the upper Oligocene (Riahi et al., 2012) is questionable; the burrows therein are mineralized and fit better to $T$. mediterranensis (García-Ramos et al., 2014). The Miocene occurrence (Rajkumar et al., 2012) is doubtful because it is poorly documented and occurs in shallow-marine sediments with shallowmarine trace fossils. 
The increase in abundance of $T$. rectum during the Cretaceous could be related to a response of burrowing organisms to both increasing organic matter delivery to the deep-sea following the evolution of calcareous algae (e.g., Erba, 2006) and increasing competition for benthic food in the deep sea by shallow as well as deep-burrowing organisms (e.g., Uchman, 2004; Buatois et al., 2016). The declining of abundance during the Oligocene can be related to climatic changes (cooling) and follows general declining trace-fossil diversity in the deep sea (Uchman, 2004).

\section{CONCLUSIONS}

Tubulichnium rectum (Fischer-Ooster, 1858) is the proper name for simple, pellet-lined burrows produced by "worm"-like organisms in deep-sea turbiditic sandstones and marls, mostly from Late Cretaceous to Eocene times. The trace makers ingested organic-rich mud deposited seasonally or episodically on the sea floor and stored faecal pellets in a deep tier beyond the depth range of other burrowers. The pellets are suggested to have been utilized as a food source during starvation times. Such behaviour represents a response to increased competition for food in the deep sea after the Cenomanian. Tubulichnium rectum is typical of the Paleodictyon and Nereites subichnofacies of the Nereites ichnofacies, mostly in distal parts of turbiditic depositional systems.

\section{ACKNOWLEDGEMENTS}

Dr. U. Menkveld-Gfeller (Naturhistorisches Museum der Burgergemeinde Bern, Switzerland) provided access to type material of Fischer-Ooster. R. Strunk (Geography, Department of Environmental Sciences, University of Basel) measured carbonate and organic matter content. T. Brustur (Bucharest) and I. Bucur (Cluj) provided updated information on the Romanian localities. D. Knaust (Stavanger) and an anonymous reviewer provided constructive and helpful criticism. Christian Meyer (Basel) provided French translation of the abstract. A.U. was supported by the Jagiellonian University (DS. funds). Additionally, his field work in Liguria (Italy) was assisted by Bruno Rattazzi (Genova) and supported by the Fondazione Luigi, Cesare e Liliana Bertora, in Austria by the Alexander von Humboldt Foundation, and the Paleontological Society, International Research Program (USA). Researches of A.U. in the Naturhistorisches Museum in Vienna received support from the SYNTHESIS Project http://www.synthesys.info/, which is financed by the European Community Research Infrastructure Action under the FP6 "Structuring the European Research Area" Programme. A.W. was supported by the Swiss National Fund (grant No. 200021_169042/1). All these contributions are gratefully acknowledged.

\section{REFERENCES}

Abel, O. 1935. Vorzeitliche Lebensspuren. Gustav Fischer, Jena.

Aller, R.C. 1994. Bioturbation and remineralization of sedimentary organic matter: effects of redox oscillation. Organic Geochemistry, 114:331-345.

Arndt, S., Jørgensen, B.B., LaRowe, D.E., Middelburg, J.J., Pancost, R.D., and Regnier, P. 2013. Quantifying the degradation of organic matter in marine sediments: A review and synthesis. Earth Science Reviews, 123:53-86.

Biseswar, R. 2005. Report on some deep-sea echiurans (Echiura) of the North-East Atlantic. Zoosystema, 27:37-46.

Bromley, R.G. 1991. Zoophycos: strip mine, refuse dump, cache or sewage farm? Lethaia, 24:460-462.

Brongniart, A.T. 1849. Tableau des generes de végétaux fossiles considérés sous le point de vue de leur classification botanique et de leur distribution géologique. Dictionnaire Universel Histoire Naturelle, 13:1-27 (152-176). Paris.

Buatois, L.A., Carmona, N.B., Curran, H.A., Netto, R.G., Mángano, M.G., and Wetzel, A.2016. The Mesozoic Marine Revolution, p. 19-134. In Mángano M.G. and Buatois L.A. (eds.), The Trace-Fossil Record of Major Evolutionary Events. Volume 2: Mesozoic and Cenozoic. Topics in Geobiology, 40. Springer, Berlin, Heidelberg, New York.

Chamberlain, C.K. 1977. Ordovician and Devonian trace fossils from Nevada. Nevada Bureau of Mines and Geology, Bulletin, 90:1-24.

Cieszkowski, M., Oszczypko, N., Zuchiewicz, W., and Uchman, A. 1992. Stop A.2.4. Lubomierz. Stratygrafia, sedymentologia i tektonika warstw z Kaniny oraz piaskowców ze Szczawiny, p. 89-94. In Zuchiewicz, W. and Oszczypko, N. (eds.), Przewodnik LXIII Zjazdu Polskiego Towarzystwa Geologicznego. Instytut Nauk Geologicznych Uniwersytetu Jagiellońskiego, Państwowy Instytut Geologiczny, Polskie Towarzystwo Geologiczne, Kraków. (In Polish)

Crimes, T.P., Goldring, R., Homewood, P., Stuijvenberg, J., and Winkler, W. 1981. Trace fossil assemblages of deep-sea fan deposits, Gurnigel and Schlieren flysch (Cretaceous-Eocene). Eclogae Geologicae Helvetiae, 74:953-995.

Cummings, J.P. and Hodgson, D.M. 2011. Assessing controls on the distribution of ichnotaxa in submarine fan environments, the Basque Basin, Northern Spain. Sedimentary Geology, 239:162-187.

Erba, E. 2006. The first 150 million years history of calcareous nannoplankton: Biosphere-geosphere inter- 
actions. Palaeogeography, Palaeoclimatology, Palaeoecology, 232:237-250.

Ettingshausen, C.R. 1863. Die fossilen Algen des Wiener und des Karpathen-Sandsteins. Sitzungsberichte der Kaiserlichen Akademie der Wissenschaften. Mathematisch-Naturwissenschaftliche Classe, Abteilung 1, 48:444-467.

Fischer-Ooster, C. 1858. Die fossilen Fucoiden der Schweizer Alpen, nebst Erörterungen über deren geologisches Alter. Huber, Bern.

Frey, R.W., Curran, A.H., and Pemberton, G.S. 1984. Trace making activities of crabs and their environmental significance: the ichnogenus Psilonichnus. Journal of Paleontology, 58:333-350.

Frey, R.W., Howard, J.D., and Pryor, W.A. 1978. Ophiomorpha: its morphologic, taxonomic, and environmental significance. Palaeogeography, Palaeoclimatology, Palaeoecology 23:199-223.

Fu, S. 1991. Funktion, Verhalten und Einteilung fucoider und lophoctenoider Lebensspuren. Courier Forschungs-Institut Senckenberg, 135:1-79.

García-Ramos, J.C., Mángano, M.G., Piñuela, L., Buatois, L., and Rodríguez-Tovar, F.J. 2014. The ichnogenus Tubotomaculum: an enigmatic pellet-filled structure from Upper Cretaceous to Miocene deepmarine deposits of southern Spain. Journal of Paleontology, 88:1189-1198.

Giannetti, A. 2010. Influence of climate, sea-level changes and tectonics and ichnoassemblages distribution in carbonate-dominated, deep-marine environment (Upper Paleocene, Zumaya section). Palaeogeography, Palaeoclimatology, Palaeoecology, 285:104-118.

Gibert, J.M., de, Netto, R.G., Tognoli, F.M.W., and Grangeiro, M.E. 2006, Commensal worm traces and possible juvenile thalassinidean burrows associated with Ophiomorpha nodosa, Pleistocene, southern Brazil. Palaeogeography, Palaeoclimatology, Palaeoecology, 230:70-84.

Häntzschel, W. 1952. Die Lebensspur Ophiomorpha Lundgren im Miozän bei Hamburg, ihre weltweite Verbreitung und Synonymie. Mitteilungen aus dem Geologischen Staatsinstitut Hamburg, 21:142-153.

Häntzschel, W. 1962. Trace fossils and problematica, p. W177-W245. In Moore, R.C. (ed.), Treatise on Invertebrate Paleontology, Part W, Miscellanea. Geological Society of America and University of Kansas Press, Boulder and Lawrence.

Häntzschel, W. 1975. Trace Fossils and Problematica, 269 pp. In Teichert, C. (ed.), Treatise on Invertebrate Paleontology, Part W, Miscellanea, Supplement I. Geological Society of America and University of Kansas, New York and Lawrence.

Heer, O. 1865. Die Urwelt der Schweiz. Zürich, Friedrich Schulthess.

Izumi, K. 2013. Geochemical composition of faecal pellets as an indicator of deposit feeding strategies in the trace fossil Phymatoderma. Lethaia, 46:496-507.
Jumars, P., Mayer, L.M., Deming, J.W., Baross, J., and Wheatcroft, R.A. 1990. Deep-sea deposit-feeding strategies suggested by environmental and feeding constraints. Philosophical Transactions of the Royal Society London, A 331:85-101.

Kern, J.P. 1978. Trails from the Vienna Wood: paleoenvironments and trace fossils of Cretaceous to Eocene flysch, Vienna, Austria. Palaeogeography, Palaeoclimatology, Palaeoecology, 23:230-262.

Knaust, D. 2008. Balanoglossites Mägdefrau 1932 from the Middle Triassic of Germany: part of a complex trace fossil probably produced by boring and burrowing polychaetes. Paläontologische Zeitschrift, 82:347-372

Knaust, D. 2013. The ichnogenus Rhizocorallium: Classification, trace makers, palaeoenvironments and evolution. Earth-Science Reviews, 126:1-47.

Knaust, D., Warchoł, M., and Kane, I.A. 2014. Ichnodiversity and ichnoabundance: Revealing depositional trends in a confined turbidite system. Sedimentology, 61:2218-2267.

Kraeuter, J., and Haven, D.S. 1970. Fecal pellets of common invertebrates of Lower York River and Lower Chesapeake Bay, Virginia. Chesapeake Sciences, 11:159-173.

Krejci-Graf, K. 1936. Zur Natur der Fucoiden. Senckenbergiana, 18:308-315.

Kristensen, E. 2000. Organic matter diagenesis at the oxic/anoxic interface in coastal marine sediments, with emphasis on the role of burrowing animals. Hydrobiologia, 426:1-24.

Książkiewicz, M. 1977. Trace fossils in the Flysch of the Polish Carpathians. Palaeontologia Polonica, 36:1208.

Kulkarni, K.G. and Panchang, R. 2015. New insights into polychaete traces and fecal pellets: Another complex ichnotaxon? PLoS ONE, 10(10): e0139933. doi:10.1371/journal.pone.0139933

Leszczyński, S. 2004. Bioturbation structures of the Kropivnik Fucoid Marls (Campanian-lower Maastrichtian) of the Huwniki - Rybotycze area (Polish Carpathians). Geological Quarterly, 48:35-60.

Lundgren, B. 1891. Studier öfver fossilförande lösa block. Geologiska Föreningen i Stockholm Förhandlinger, 13:111-121.

Lutz, M.J., Caldeira, K., Dunbar, R.B., and Behrenfeld, M.J. 2007. Seasonal rhythms of net primary production and particulate organic carbon flux describe biological pump efficiency in the global ocean. Journal of Geophysical Research, 112:C 10011, 1-26.

Massalongo, A.D.B. 1856. Studii palaeontologici. Antonelli, Verona.

Mayer, G. 1952. Neue Lebensspuren aus dem Unteren Hauptmuschelkalk (Trochitenkalk) von Wiesloch: Coprulus oblongus n. sp. und C. sphaeroideus n. sp. Neues Jahrbuch für Geologie und Paläontologie, Monatshefte, 1952:376-379. 
Mikuláš, R. and Uchman, A. 1996. Note on rediscovered type and figured material relating to Muensteria Sternberg 1833. Ichnos, 4:305-309.

Mutti, E. 1992. Turbidite Sandstones. AGIP, San Donato Milanese.

Netto, R.G., Curran, H.A., Belaústegui, Z., and Tognoli, F.M.W. 2017. Solving a cold case: New occurrences reinforce juvenile callianassids as the Ophiomorpha puerilis tracemakers. Palaeogeography, Palaeoclimatology, Palaeoecology, 475:93-105.

Papp, A. 1942. Agglutinierende Polychäten aus dem oberen Miozän. Paleobiologica, 7(4) (for 1941):318324.

Pomel, L. 1849. Materiaux pour servir a la flore fossile des terrains jurassiques de la France. Amtliche Berichte über die Versammlung der Gesellschaft deutscher Naturforscher und Ärzte Aachen, 25:254332.

Popkov, D.V. 1992. A new echiuran species Thalassema malakhovi (Echiura) from New Zealand. New Zealand Journal of Marine and Freshwater Research, 26:379-383.

Rajkumar, H.S., Khaidem, K.S., Soibam, I. and Sanasam, S. 2012. Palaeoenvironment of the Middle Bhuban, Surma Group of Mizoram, India: An ichnological approach. Journal of the Indian Association of Sedimentologists, 31:65-79.

Reis, O.M. 1909. Zur Fucoidenfrage. Jahrbuch der Kaiserlich-Königlichen Geologischen Reichsanstalt, 59:615-638.

Riahi, S., Uchman, A., Stow, D., Soussi, M., and Ben Ismail Lattrache, K. 2014. Deep-sea trace fossils of the Oligocene-Miocene Numidian Formation, northern Tunisia. Palaeogeography, Palaeoclimatology, Palaeoecology, 414:155-177.

Schimper, W. P. and Schenk, A., 1879-1890. Palaephytologie. In: Handbuch der Palaeontologie. II Abtheilung. Oldenbourg, München und Leipzig, $152 \mathrm{pp}$.

Schweizerische Geologische Kommission 1961. Geologischer Atlas der Schweiz, Blatt 36 Gurnigel. Schweizerische Geologische Kommission, Bern.

Seilacher, A. 1959. Zur ökologischen Charakteristik von Flysch und Molasse. Eclogae Geologicae Helvetiae, 51(1958):1062-1078.

Seilacher, A. 2007. Trace Fossil Analysis. Springer, Berlin, Heidelberg, New York.

Stow, D.A.V., Reading, H.G., and Collinson, J.D. 1996. Deep seas, p. 395-453. In Reading, H.G. (ed.), Sedimentary Environments: Processes, Facies and Stratigraphy. Blackwell, Oxford.

Thomas, I.M. 1972. Action of the gut in Saccoglossus otagoensis (Hemichordata: Enteropneusta). New Zealand Journal of Marine and Freshwater Research, 6:560-569.

Tunis, G. and Uchman, A. 1993. Trace fossils in the "Flysch del Grivó" (Lower Tertiary) in the Julian Prealps, NE Italy: Preliminary observations. Gortania, 14:71-104.
Tunis, G. and Uchman, A. 1996. Trace fossil and facies changes in the Upper Cretaceous-Middle Eocene flysch deposits of the Julian Prealps (Italy and Slovenia): consequences of regional and world-wide changes. Ichnos, 4:169-190.

Uchman, A. 1991a. Diverse tiering patterns in Paleogene flysch trace fossils, Magura nappe, Carpathians, Poland. Ichnos, 1:287-292.

Uchman, A. 1991b. Trace fossils from stress environments in Cretaceous-Paleogene flysch of the Polish Outer Carpathians. Annales Societatis Geologorum Poloniae, 61:207-220.

Uchman, A. 1991c. Skamieniałości śladowe z warstw inoceramowych oraz utworów formacji szczawnickiej (fm) w strefie krynickiej i bystrzyckiej płaszczowiny magurskiej (Trace fossils of the Inoceramian beds and the Szczawnica Formation in the Krynica and Bystrzyca Zones of the Magura Nappe). Przegląd Geologiczny, 39(4):207-212. (In Polish, with English summary)

Uchman, A. 1992a. Ichnofuna formacji szczawnickiej, p. 55. In Zuchiewicz, W. and Oszczypko, N. (eds.), Przewodnik LXIII Zjazdu Polskiego Towarzystwa Geologicznego. Instytut Nauk Geologicznych Uniwersytetu Jagiellońskiego, Państwowy Instytut Geologiczny, Polskie Towarzystwo Geologiczne, Kraków. (In Polish)

Uchman, A. 1992b. An opportunistic trace fossil assemblage from the flysch of the Inoceramian beds (Campanian-Palaeocene), Bystrica Zone of the Magura Nappe, Carpathians, Poland. Cretaceous Research, 13:539-547.

Uchman, A. 1995. Taxonomy and palaeoecology of flysch trace fossils: The Marnoso-arenacea Formation and associated facies (Miocene, Northern Apennines, Italy). Beringeria, 15:3-115.

Uchman, A. 1999. Ichnology of the Rhenodanubian Flysch (Lower Cretaceous-Eocene) in Austria and Germany. Beringeria, 25:65-171.

Uchman, A. 1998. Taxonomy and ethology of flysch trace fossils: A revision of the Marian Książkiewicz collection and studies of complementary material. Annales Societatis Geologorum Poloniae, 68:105218.

Uchman, A. 1999. Ichnology of the Rhenodanubian Flysch (Lower Cretaceous-Eocene) in Austria and Germany. Beringeria, 25:65-171.

Uchman, A. 2004. Phanerozoic history of deep-sea trace fossils, p. 125-139. In Mcllroy, D. (ed.), The application of ichnology to palaeoenvironmental and stratigraphic analysis. Geological Society, London, Special Publication, 228.

Uchman, A. 2007a. Trace fossils of the Pagliaro Formation (Paleocene) in the North Apennines, Italy. Beringeria, 37:217-237.

Uchman, A. 2007b. Deep-sea trace fossils from the mixed carbonate-siliciclastic flysch of the Monte Antola Formation (Late Campanian-Maastrichtian), 
North Apennines, Italy. Cretaceous Research, 28(6):980-1004.

Uchman, A. 2008a. Stop 6 - Krościenko-Łąkcica Szczawnica Formation (Paleocene - lower Eocene): ichnology of eutrophic flysch deposits, p. 119-121. In Pieńkowski, G. and Uchman, A. (eds.), Ichnological Sites of Poland; The Holy Cross Mountains and the Carpathian Flysch; The Second International Congress on Ichnology, Cracow, Poland, August 29September 8, 2008; Pre-Congress and Post-Congress Field Trip Guidebook. Polish Geological Institute, Warszawa.

Uchman, A. 2008b. Stop 11 - Słopnice - Ropianka Formation (Senonian-Palaeocene) and Variegated Shale (Eocene), p. 136-138. In Pieńkowski, G. and Uchman, A. (eds.), Ichnological Sites of Poland; The Holy Cross Mountains and the Carpathian Flysch; The Second International Congress on Ichnology, Cracow, Poland, August 29-September 8, 2008; PreCongress and Post-Congress Field Trip Guidebook. Polish Geological Institute, Warszawa.

Uchman, A. 2008c. Cretaceous - Neogene flysch deposits of the Outer Carpathians, p. 24-65. In Uchman, A. (ed.), Types of Invertebrate Trace Fossils from Poland: An Illustrated Catalogue. Polish Geological Institute, Warszawa.

Uchman, A. 2009. Deep-Sea Life in the Geological Past: Body Fossils and Trace Fossils of the Monte Antola Formation, Northern Apennines. Fundazione Luigi, Cesare e Liliana Bertora, Genova.

Uchman, A. and Rattazzi, B. 2017a (2016 online). Rhizocorallium hamatum (Fischer-Ooster, 1858), a Zoophycos-like trace fossil from deep-sea CretaceousNeogene sediments. Historical Biology, 29(3):395410. DOI: 10.1080/08912963.2016.1167481.

Uchman, A. and Rattazzi, B. 2017b. The trace fossil Polykampton cabellae isp. nov. from the Pagliaro Formation (Paleocene), Northern Apennines, Italy: a record of nutritional sediment sequestration by a deep sea invertebrate. Ichnos, http://dx.doi.org/ 10.1080/10420940.2017.1308362

Uchman, A. and Wetzel, A. 2012. Deep-sea fans, p. 643671. In Bromley, R.G. and Knaust, D. (eds.), Trace
Fossils as Indicators of Sedimentary Environments. Developments in Sedimentology, 64.

Uchman, A. and Wetzel, A. 2016. Sequestrichnia - a new ethological category of trace fossils in oligotrophic deep-sea environments, p. 190. In Baucon, A., Neto de Carvalho, C., and Rodrigues, J. (eds.), Ichnia 2016, Abstract Book. UNESCO Geopark Naturejo, International Ichnological Association, Castelo Branco.

Vallon, L.H., Rindsberg, A.K., and Bromley, R.G. 2016. An updated classification of animal behaviour preserved in substrates. Geodinamica Acta, 28:5-20.

van Stuijvenberg, J. 1979. Geology of the Gurnigel area (Prealps, Switzerland). Beiträge zur Geologischen Karte der Schweiz, 151. Schweizerische Geologische Kommission, Bern.

Vialov, O.S. 1966. Sledy zhiznedeyatelnosti organizmov $i$ ikh paleontologicheskoye znachenye. Naukova Dumka, Kiev. (In Russian)

von Sternberg, K.M. 1833. Versuch einer geognostischbotanischen Darstellung der Flora der Vorwelt, Teil 5 und 6. J.Spurny, Prague.

Watelet, A.S. 1866. Description des Plantes Fossiles de Bassin de Paris. J.-B. Baillère et Fils, Paris.

Wetzel, A. 2008. Recent bioturbation in the deep South China Sea: A uniformitarian ichnologic approach. Palaios, 23:601-615.

Wetzel, A. and Uchman, A. 1998. Deep-sea benthic food content recorded by ichnofabrics: A conceptual model based on observations from Paleogene flysch, Carpathians, Poland. Palaios, 13:533-546.

Wetzel, A. and Uchman, A. 2001. Sequential colonization of muddy turbidites: examples from Eocene Beloveža Formation, Carpathians, Poland. Palaeogeography, Palaeoclimatology, Palaeoecology, 168:171-186.

Wetzel, A., Blechschmidt, I., Uchman, A., and Matter, A. 2007. A highly diverse ichnofauna in late Triassic deep-sea fan deposits of Oman. Palaios, 22:567576.

Wetzel, A. and Unverricht, D. 2013. A muddy megaturbidite in the deep central South China Sea deposited 230 yrs BP. Marine Geology, 346:91-100. 